\title{
Influence of Correcting the Acidity of Soil and Usage of Potassium Fertilizers on Physiological, Biochemical Characteristics and Storage Capacity of the Autumn Cabbage
}

\author{
Marian I. BOGOESCU \\ Research and Development Institute for Industrialization and Marketing of Horticultural Products "Horting", 5 N Drumul Gilăului Street, \\ Sector 4, 041715 Bucharest, Romania; bogoescumarian@gmail.com (*corresponding author)
}

\begin{abstract}
Soils are generally fertile in Romania but there are numerous areas with less favourable characteristics, which are, however, planted with cabbage, as consumers' request and economic needs make it necessary. Variable factors which determined the setup of the experimental variants were represented by the amendments applied (calcium carbonate) and chemical fertilizers containing potassium. The experimental plots have been organized in three locations with podzolic soils. The research has been focused on the influence of correcting soil acidity and applying potassium fertilization on the qualitative changes and the storage capacity of the autumn white cabbage. Correcting the reaction and the supply of podzolic, acid and low in potassium soils, resulted in a positive change of the cabbage leaves mineral composition, in achieving an optimal ratio between calcium and magnesium - adequate to normal metabolic processes-and in statistically significant reduction of the cells membranes permeability. A significant increase of content in soluble dry substance, soluble carbohydrates and chlorophyll was noticed in the cabbage leaves; titratable acidity increased, but it was not statistically ensured. A significant increase in the production of the marketable cabbage was obtained by applying calcium carbonate corrections on acid soils and by administrating potassium salts; significant positive differences were found on cabbage crops grown on soils with a lower supply in potassium. Significant reduction of the losses caused by evapotranspiration, decay and conditioning, as well as of the total losses were analysed after 140 days of storage.
\end{abstract}

Keywords: chlorophyll, limestone, mineral composition, potassium fertilizer, soluble carbohydrates, total losses, yield

\section{Introduction}

With a very high production potential, cabbage is a vegetable that is a very important source of vitamin $\mathrm{C}$ (Gould et al., 2006) and has a very high antioxidant potential (Nilsson et al., 2006). Fowke et al. (2003), show that cabbage has, besides its very high contents of vitamin C, an appreciable amount of potassium. One hundred grams of cabbage (edible substance) contains $4.6 \mathrm{~g}$ of carbohydrates, $1.8 \mathrm{~g}$ of protein, $0.1 \mathrm{~g}$ of fat, $0.6 \mathrm{~g}$ of mineral substances, 29 $\mathrm{mg}$ of calcium, $0.8 \mathrm{mg}$ of iron, $14.1 \mathrm{mg}$ of sodium. In addition, cabbage is a rich source of vitamin A (FAO, 2000). Previous research has shown that constantly consumed cabbage provides significant benefits to the cardiovascular system (Beecher, 1994), reduces the risk of several cancers, especially lung, colon, breast, ovarian and bladder cancer (Ojetayo et al., 2011). The morphological characteristics, biochemical components and nutritional value determined the cultivation of this species on an area of over 54,900 ha in 2013 (NIS, 2015) and places it among the most cultivated and appreciated vegetables by consumers in Romania. As a result, Romania ranks among the top ten world-wide cabbage producers, with an annual output of over one million tons (FAO, 2014).

In Romania, the soils in the regions where cabbage is cultivated are generally fertile, having particularly favourable characteristics for the growth and development of vegetables, implicitly for cabbage crops with a high percentage of marketable production and a good capacity to maintain quality. However, there are many soils with less favourable features for the growth and development of vegetables, which are exploited because the consumers and the economic needs require the cultivation of vegetables on these surfaces, as well. Various particular conditions have imposed cabbage cultivation, even in areas with tradition in the realization of this crop, on acidic soil, poor in assimilated potassium. Because, in most cases, the cabbage obtained on 
492

these fields had an inadequate capacity, it was necessary to carry out research on the qualitative changes and the storage capacity of the autumn white cabbage under conditions of correcting soil acidity and applying potassium fertilisers. A significant proportion in these fields cultivated with cabbage of different types is held by podzolic soils having some general specific characteristics: sandy-loamy or clayey texture; they contain $1-3 \%$ humus; $\mathrm{Ca}=0.3-0.6 \% ; \mathrm{N}$ total $=0.11-0.17 \%$; $\mathrm{P}$ total $=0.09 \% ; \mathrm{K}$ total $=0.08-1.00 \% ; \mathrm{pH}=$ 4.5-6.0\% (Obrejeanu and Puiu, 1972). The fertility of these soils is poor, often requiring the correction of the soil reaction by using calcareous amendments and fertilization with high doses of organic and mineral fertilizers. These types of soil occur in all regions of the country, especially where annual rainfall exceeds $700 \mathrm{~mm}$ and the average annual temperature is $7.5^{\circ} \mathrm{C}$. If in the area of the Western Plain and in the South and South-East Plain, these types of soil do not exceed 3-5\% of the total field area, in the northern part of Oltenia and Muntenia they reach 34-52\%. In the area of Moldavian Plateau, between Prut and Siret, they exceed 28.4\%, in the Transylvanian Plateau area, 21.9\%, in the Someșan Plateau area, $17.4 \%$ (Bâlteanu et al., 1974). To ensure an efficient technological process, cabbage requires $60-85 \mathrm{~kg} \mathrm{~N} \mathrm{ha}^{-1} ; 60-80 \mathrm{~kg} \mathrm{P}_{2} \mathrm{O}_{5} \mathrm{ha}^{-1}$ and $30-90 \mathrm{~kg}$ of $\mathrm{K}_{2} \mathrm{O}$ ha $^{-1}$ (Shika and Doug, 2001). Wijevardena and Amarasiri (1993), mention that cabbage removes higher amounts of potassium from soil than other vegetable crops, due especially to the very high amount of biomass it produces. Regarding this particularity of the cabbage crop, Bhardwaj et al. (2000), respectively Din et al. (2007), reported a superior quality of the yield and nutritional value in case of cabbage that benefited from a $60 \mathrm{~kg} \mathrm{~N}^{-1}$ fertilization from organic fertilizer sources as well as NPK from mineral fertilizers. Ojetayo et al. (2011), shows that the nitrogen, phosphorus and potassium forms, easily assimilable from mineral fertilizers and with slow release from organic fertilizers, can increase the mineral content $(\mathrm{Ca}, \mathrm{Mg}$ and $\mathrm{K})$ of cabbage both before and after storage. Referring to the fertilization of Brassicas genus cultures, Ghuge et al. (2007) states that adequate content of phosphorus, potassium and calcium oxide in soil is particularly important for optimal plant growth. In this respect, the experiments organized with white cabbage by Atanasova et al. (2007), revealed that the production of white cabbage with the best nutritional quality parameters (the highest content of soluble carbohydrates and vitamin $\mathrm{C}$ and a low content in nitrates and cellulose) was obtained as a result of foliar fertilization with nitrogen, phosphorus and potassium and concludes that white cabbage is a crop hat requires high nutrient consumption (nitrogen, phosphorus, potassium) as this culture produces a very high vegetative biomass in a relatively short vegetation period; this research revealed that the changes identified in the soil $\mathrm{pH}$ were statistically insignificant following the application of mineral and organic fertilizer to the soil or of foliar ones in the vegetation.

Potassium is an essential nutrient for increasing the productivity of vegetable crops and is in a significant positive relationship with their quality attribute (Bidari and Hebsur, 2011). The amount of vitamin $C$ also depends on the potassium nutrition of the plant (Perkins-Veazie and Roberts, 2003). Marschner (2011) mentions that potassium has a significant contribution to plant photosynthesis, enzymatic activity of cells, maintains cell turgor and is involved in ionic homeostasis.

The research carried out in this paper has been focused on the influence of correcting soil acidity and applying potassium fertilization on the yield, qualitative changes and the storage capacity of the autumn white cabbage.

\section{Materials and Methods}

\section{Location and sampling design}

One of the most common Romanian cultivars of autumn white cabbage, the 'De Buzau' variety, was used to perform the experiments. They have been carried out in three locations with different soil characteristics; two levels of amendment with calcium carbonate and mineral fertilization with potassium were applied on the experimental plots.

The variables that determined the organization of the experimental variants were:

$$
\begin{aligned}
& \text { a. Amendments }\left(\mathrm{CaCO}_{3}\right) \\
& a_{1}=0.0 \text { tha }^{-1} \\
& a_{2}=4.5 \text { tha }^{-1} \\
& \text { b. Mineral fertilisers }\left(\mathrm{K}_{2} \mathrm{O}\right) \\
& \mathrm{b}_{1}=60 \mathrm{kgha}^{-1} \text { active substance } \\
& \mathrm{b}_{2}=240 \mathrm{kgha}^{-1} \text { active substance } \\
& \text { c. Location } \\
& c_{1}=\text { Micoşlaca (Tarnavelor Plateau) } \\
& c_{2}=\text { Mocira (Baia-Mare Basin) } \\
& c_{3}=\text { Codlea (Bârsei Basin) }
\end{aligned}
$$

Calcium carbonate was applied as limestone and potassium in the commercial form of potassium salt, having an active substance content of $34 \% \mathrm{~K}_{2} \mathrm{O}$. All experimental variants were fertilized equally with $150 \mathrm{kgha}^{-1}$ active

\begin{tabular}{|c|c|c|c|c|c|c|c|}
\hline \multirow{2}{*}{ Location } & \multirow{2}{*}{ Soil type } & \multirow{2}{*}{$\mathrm{pH}^{(+\cdots)}$} & \multirow{2}{*}{$\begin{array}{c}\text { Humus } \\
(\%)\end{array}$} & $\left.\mathrm{P}^{*}\right)$ & $\mathrm{K}^{* \prime)}$ & $\mathrm{Ca}$ & $\mathrm{Mg}^{2+1}$ \\
\hline & & & & \multicolumn{4}{|c|}{ ppm } \\
\hline Micloşlaca (Tarnavelor Plateau) & Brown podzolic & 4.9 & 1.71 & 18 & 54 & 314 & 28 \\
\hline Mocira (Baia-Mare Basin) & Clay-illuvial, slightly pseudogley podzolic & 5.1 & 2.03 & 52 & 111 & 321 & 63 \\
\hline Codlea (Bârsei Basin) & Clay-illuvial, pseudogley podzolic & 4.8 & 1.80 & 59 & 78 & 272 & 84 \\
\hline
\end{tabular}
substance $\mathrm{N}$ and $80 \mathrm{~kg} \mathrm{ha}^{-1}$ active substance $\mathrm{P}_{2} \mathrm{O}_{5}$, applied in the commercial form of ammonium nitrate with an active substance content of $33 \%$, or concentrated superphosphate, with an active substance content of $40 \%$. Experimental plots were organized on acid-reactive fields $(\mathrm{pH}=4.8-5.1)$ and a low-to-medium potassium supply (Table 1). The amendments and fertilizers were applied prior to planting of cabbage seedlings to a depth of about $10 \mathrm{~cm}$.

Table 1. Characterization of experimental plots fertility level 


\section{Experimental procedures}

Autumn cabbage seedlings of 40-day-old were planted in the period June 15-20; the culture establishment and maintenance works following the frame technology developed by the Romanian profile institute (ICLF Vidra).

The cabbage leaf analysis was performed at the time of cabbage head formation. For each aspect studied were taken samples of 20 leaves, from the medium area of the cabbage head, which after calcinations, were analysed to determine the content of macro-elements $(\mathrm{K}, \mathrm{Ca}$ and $\mathrm{Mg})$ using the atomic absorption spectrophotometric method.

The content of soluble carbohydrates was determined by estimating their proportion (mono and di-carbohydrates) in the edible fresh substance. For this, the liquid chromatographic method with ELSD detection was used by simultaneous individual quantification of the glucose, fructose and sucrose content.

The content in organic acids (titratable acidity) was determined by direct neutralization of cabbage extracts.

Determination of the content of chlorophyll pigments was performed by spectrophotometric analysis with UV detection of the extracts:

- acetone extraction (Mackiney method) and

- acetone-heptane mixture extraction (Masuko-Nagata method).

Conductivity detection, by mannitol extraction, was used to determine cell membrane permeability. Expression of the results was made in $\mu$ s and reported on $10 \mathrm{~g}$ of fresh product.

The soluble dry substance (\%) was determined refractometrically using the $\mathrm{ABBE}$ refractometer.

Observations and determinations were carried out on sections of cabbage head (chlorophyll, mineral elements, etc.), from cell pressed juice (soluble dry substance, titratable acidity, cell membrane permeability, etc.) or aqueous extracts from boiling and filtering sections of cabbage head (soluble carbohydrates).

Cabbage harvesting was carried out in the third decade of October. The cabbage samples, corresponding to the researched variants, were stored in "P"-type plastic crates, in experimental refrigerated cells of ICDIMPH-HORTING and kept under refrigeration conditions (temperature $=$ $0 \pm 0.5^{\circ} \mathrm{C}$, relative air humidity $=90-92 \%$ ), for a period of 140 days.

Quantitative determinations were made on the marketable crop regarding evapotranspiration losses, decay and conditioning, respectively total losses.

\section{Statistical procedure}

The statistical processing of the experimental results obtained was done according to the methods applied in biology and agriculture. Testing the significance of the different experimental variants results to the control variant was done by analysis of variance (LSD for $\mathrm{a}=0.05 \%$ ).

\section{Results and Discussion}

Mineral composition of cabbage leaves under conditions of administration of calcium carbonate amendments and potassium fertilizers on acidic soils

The administration of calcium carbonate amendments in the case of acidic podzols led to a change in the mineral composition of autumn white cabbage leaves (Table 2).

Applying calcium carbonate soil amendment, in the amount of $4.5 \mathrm{t} \mathrm{ha}^{-1}$ limestone, resulted in a significant increase in the calcium content of the cabbage leaves. Thus, if under acidic soil conditions, the leaf calcium content was $1.7 \%$, relative to the dry substance, with the $\mathrm{CaCO}_{3}$ amended variant, there was an increase in the calcium content by $0.4 \%$, relative to dry substance.

The potassium content of the cabbage leaves, relative to dry substance, was lower in the case of $\mathrm{CaCO}_{3}$ - amended variant compared to the variant with no amendments (2.6\%, respectively $2.9 \%$ potassium), but it was above the value considered as the minimum threshold for good metabolic activity [according to Geissler (1953), the minimum threshold is $2.5 \%$ potassium, relative to dry substance].

At the same time, in the amended variant was determined a magnesium content of $0.67 \%$ was relative to dry substance, $0.28 \%$ higher than that determined in the original variant, where the magnesium content of cabbage leaf was $0.39 \%$.

Correcting the soil reaction by administering calcium carbonate amendments helped achieving an optimal ratio of calcium and magnesium at the level of cabbage head leaves.

If in the case of a experimental plots with podzolic soil, which has not been treated with calcium carbonate, the $(\mathrm{Ca} / \mathrm{Mg})$ ratio determined in the cabbage head leaves was of 4.4, with $45.3 \%$ higher than normal, in the cabbage head leaves coming from the calcium carbonate treated soils this ratio was only 3.1, very close to the optimum, according to Welch et al. (1985), in fresh vegetables the optimal ratio $\mathrm{Ca} / \mathrm{Mg}$ is three.

Analyses on the calcium content of autumn white cabbage leaves, as a result of potassium salt fertilization (Table 3), did not reveal significant differences between variants; leaf content in calcium was between $1.7 \%$ and $1.6 \%$, respectively.

Variants fertilized by application of potassium fertilizers, in the amount of $240 \mathrm{~kg} \mathrm{tha}^{-1}$ active substance $\mathrm{K}_{2} \mathrm{O}$, showed a distinctly significant increase in potassium content, compared to those with only $60 \mathrm{~kg} \mathrm{ha}^{-1}$ active substance

Table 2. Effect of calcium carbonate amendments on the mineral composition of cabbage head leaves

\begin{tabular}{cccc}
\hline $\begin{array}{c}\text { Correction of soil } \mathrm{pH} \text { with limestone } \\
\left(\mathrm{CaCO}_{3}\right) \\
\left(\mathrm{tha}^{-1}\right)\end{array}$ & \multicolumn{2}{c}{ The main mineral elements in the leaf of autumn white cabbage head $(\%)$} \\
\cline { 2 - 4 } Calcium & Potassium & 2.9 \\
\hline 4.5 & 1.7 & $2.6^{\circ}$ & 0.39 \\
LSD & $2.1^{*}$ & 0.15 & $0.67^{*}$ \\
\hline
\end{tabular}


Table 3. Effect of potassium mineral fertilizers on mineral composition of cabbage leaves

\begin{tabular}{cccc}
\hline Potassium mineral fertilizers & \multicolumn{3}{c}{ The main mineral elements in the leaf of autumn white cabbage head (\%) } \\
\cline { 2 - 4 }$\left(\mathrm{kg} \mathrm{ha}^{-1}\right.$ active substance $\left.\mathrm{K}_{2} \mathrm{O}\right)$ & Calcium & Potassium & Magnesium \\
\hline 60 & 1.7 & 1.9 & 0.62 \\
240 & 1.67 & $3.3^{*}$ & $0.44^{*}$ \\
LSD & 0.09 & 0.94 & 0.11 \\
\hline
\end{tabular}

Table 4. Influence of applying limestone amendment to acidic soils on cabbage leaves chlorophyll pigments content and cell membranes permeability

\begin{tabular}{ccc}
\hline $\begin{array}{c}\text { Correction of soil } \mathrm{pH} \text { with limestone }\left(\mathrm{CaCO}_{3}\right) \\
\left(\mathrm{t} \mathrm{ha}^{-1}\right)\end{array}$ & $\begin{array}{c}\text { Chlorophyll pigments } \\
(\mathrm{mg} / 100 \text { g edible part })\end{array}$ & $\begin{array}{c}\text { Permeability } \\
\text { index }\end{array}$ \\
\hline 0 & 15.68 & 3.56 \\
4.5 & $21.60^{*}$ & $2.4^{\circ}$ \\
LSD & 4.62 & 0.94 \\
\hline
\end{tabular}

$\mathrm{K}_{2} \mathrm{O}$; from a potassium content of $1.9 \%$, by additional fertilization the potassium content of the leaves increased to $3.3 \%$, level considered to be appropriate for the normal development of metabolic processes (Geissler, 1953).

Application of potassium fertilizers, in the amount of $240 \mathrm{~kg} \mathrm{ha}^{-1}$ active substance $\mathrm{K}_{2} \mathrm{O}$ led to a distinctly significant decreased content of cabbage leaves in magnesium from $0.62 \%$ to $0.44 \%$. Under these conditions, the normal concentration of the leaves in magnesium, 0.20$0.40 \%$ relative to dry substance, according to Geissler (1953) and a balanced $\mathrm{Ca} / \mathrm{Mg}$ ratio of 3.6 contributed to the normal development of physiological and biochemical processes in the cabbage leaves. The recorded data are in line with the results obtained by Wang et al. (2004), which state that an additional input of potassium fertilizer led to the increase of potassium content and the decrease of magnesium and calcium content in cabbage leaves.

The application of amendments on acidic soils determined the modification of some biochemical and physiological indicators of autumn white cabbage leaves, respectively the significant increase in the chlorophyll pigments content of cabbage leaves and the significant reduction of cell membranes permeability (Table 4).

The chlorophyll content of leaves increased from 15.68 $\mathrm{mg} / 100 \mathrm{~g}$ edible part to $21.60 \mathrm{mg} / 100 \mathrm{~g}$, with positive influences on obtaining a superior quality of cabbage heads. In this respect, Lester et al. (2005), mention that the potassium input in the culture leads to the improvement of pigments, carbohydrates and ascorbic acid amount in the plant. A similar conclusion was reached by Marschner (2011) which states that potassium has an important contribution to the process of cabbage photosynthesis. Rao and Subramanian (1991), observed that increasing the potassium dose applied to the white cabbage culture leads to significant increases in the potassium content of the plant in all its phenophases.

The cell membrane permeability, expressed by - the permeability index - determined as the ratio between cell membrane permeability and free ion concentration in the solution, diminished by $32.3 \%$, in absolute values from 3.56 to 2.41 , which indicated a physiological activity relevant to a metabolism that can determine a relatively high storage capacity of cabbage heads, the results are consistent with the research carried out by Burzo et al. (1990).
Under the conditions of applying potassium fertilizers, a significant increase in the content of soluble dry substance, soluble carbohydrates and chlorophyll in cabbage leaves was registered; an increase in titratable acidity was determined, but it was not statistically significant (Table 5); similarly, Adams (1991) mentions that applying potassium fertilizers to culture does not lead to a significant increase in titratable acidity.

Thus, the soluble dry substance increased by $1.5 \%$, a result also confirmed by the research made by Sima et al. (2014), Iakovskaia (1967), the content in soluble carbohydrates was higher by $1.2 \%$ and the chlorophyll content in leaves increased from $16.40 \mathrm{mg} / 100 \mathrm{~g}$ to 20.56 $\mathrm{mg} / 100 \mathrm{~g}$ edible part. Previously, Guo et al. (2004) mentions that potassium fertilization leads to a significant increase in carbohydrate and ascorbic acid content in cabbage and attenuates the unfavourable effect of irrational application of nitrogen. Vanparys and Seynnaeve (1998), studying the effect of applying a $200 \mathrm{kgha}^{-1}$ potassium dose, came to the same conclusion, meaning that there were significant differences in the content of soluble dry substance, vitamin $\mathrm{C}$ and commercial quality in the cabbage.

\section{Influence of correcting soil acidity and applying potassium} fertilizers on the cabbage reaction to storage

Applying calcium carbonate amendments on acidic soils led to a significant increase in marketable production. If in the variant corresponding to the soil where no amendments were applied, the marketable production (white autumn cabbage, which had quality characteristics corresponding to the quality I according to STAS-3597-85), was 26.7-42.3 tha $^{-1}$, in the variant which included soils with calcium carbonate amendments applied, a cabbage production ranging from 33.6-48.5 tha ${ }^{-1}$ was obtained. Marketable production, made on the fields of Mocira locality, increased due to soil amendment, but did not show statistically ensured differences (Table 6).

The particularly favourable effect of calcium carbonate application on marketable production, particularly on higher acidity soils ( $\mathrm{pH}$ between 4.8-4.9), was highlighted. For all three localities, the average of marketable cabbage production obtained on the amended areas showed a significant increase by 5.4 tha $^{-1}$, representing $15.3 \%$. Similar 
Table 5.Influence of applying potassium fertilizers on some biochemical quality indicators for autumn white cabbage

\begin{tabular}{ccccc}
\hline $\begin{array}{c}\text { Potassium mineral fertilizers } \\
\left(\mathrm{kg} \mathrm{ha}^{-1} \text { active substance } \mathrm{K}_{2} \mathrm{O}\right)\end{array}$ & $\begin{array}{c}\text { Soluble dry substance } \\
(\%)\end{array}$ & $\begin{array}{c}\text { Soluble carbohydrates } \\
(\%)\end{array}$ & $\begin{array}{c}\text { Titratable acidity } \\
(\%)\end{array}$ & $\begin{array}{c}\text { Chlorophyll pigments } \\
(\mathrm{mg} / 100 \mathrm{~g})\end{array}$ \\
\hline 60 & 5.4 & 1.9 & 0.19 & 16.40 \\
240 & $6.9^{*}$ & $3.2^{*}$ & 0.21 & $20.56^{*}$ \\
LSD & 1.2 & 1.1 & 0.11 & 3.14 \\
\hline
\end{tabular}

Table 6. Effect of applying calcium carbonate amendment and potassium fertilization on marketed production of autumn white cabbage

\begin{tabular}{|c|c|c|c|c|c|}
\hline \multirow{4}{*}{ Specification } & & \multicolumn{4}{|c|}{ Marketed production $\left(\mathrm{t} \mathrm{ha}^{-1}\right)$} \\
\hline & & \multirow{3}{*}{$\begin{array}{l}\text { Târnavelor Plateau } \\
\text { Micoşlaca }\end{array}$} & \multirow{3}{*}{$\begin{array}{c}\text { Baia-Mare } \\
\text { Basin } \\
\text { Mocira }\end{array}$} & \multirow{3}{*}{$\begin{array}{c}\text { Bârsei } \\
\text { Basin } \\
\text { Codlea }\end{array}$} & \multirow{3}{*}{ Average } \\
\hline & & & & & \\
\hline & & & & & \\
\hline \multirow{3}{*}{ Calcium carbonate amendment $\left(\mathrm{tha}^{-1}\right)$} & 0.0 & 42.3 & 37.2 & 26.7 & 35.4 \\
\hline & 4.5 & $48.5^{*}$ & 40.4 & $33.6^{*}$ & $40.8^{*}$ \\
\hline & LSD & 5.9 & 3.4 & 5.4 & 4.7 \\
\hline \multirow{3}{*}{$\begin{array}{c}\text { Potassium fertilization } \\
\left(\mathrm{kgha}^{-1} \text { active substance } \mathrm{K}_{2} \mathrm{O}\right)\end{array}$} & 60 & 43.8 & 37.4 & 28.7 & 36.6 \\
\hline & 240 & $47.0^{*}$ & 40.2 & $31.6^{*}$ & $39.6^{*}$ \\
\hline & LSD & 2.6 & 3.1 & 2.3 & 2.4 \\
\hline
\end{tabular}

Table 7. Effect of applying calcium carbonate amendments and potassium fertilization on losses registered by autumn white cabbage, after storage

\begin{tabular}{ccccc}
\hline \multirow{2}{*}{ Specification } & & \multicolumn{3}{c}{ Losses (\%) } \\
\cline { 3 - 5 } & & Evapo-transpiration & Decay and conditioning & Total \\
\hline Calcium carbonate & 0.0 & 9.5 & 13.8 & 23.3 \\
amendment $\left(\mathrm{t} \mathrm{ha}^{-1}\right)$ & 4.5 & $5.8^{*}$ & $9.4^{*}$ & $15.2^{*}$ \\
& $\mathrm{LSD}$ & 3.1 & 3.8 & 4.7 \\
Potassium fertilization & 60 & 8.4 & 12.9 & 21.3 \\
$\left(\mathrm{~kg} \mathrm{ha}^{-1}\right.$ active substance $\left.\mathrm{K}_{2} \mathrm{O}\right)$ & 240 & 6.9 & $10.3^{*}$ & $17.2^{*}$ \\
& $\mathrm{LSD}$ & 2.3 & 2.1 & 3.9 \\
\hline
\end{tabular}

results were registered under conditions of potassium salt fertilization, with significant, positive, differences highlighting the marketed production obtained on field with a lower supply of potassium (Micoşlaca, $54 \mathrm{ppm}$, and Codlea, $78 \mathrm{ppm}$ ), given a dose of $240 \mathrm{kgha}^{-1}$ active substance $\mathrm{K}_{2} \mathrm{O}$. Marketable cabbage production, calculated as an average of the results registered in all crop areas, showed a significant increase, statistically ensured, of 3.0 tha $^{-1}$, representing $8.2 \%$. Similar results have also been reported by Zhou et al. (2001), which shows that at the $225 \mathrm{kgha}^{-1} \mathrm{~K}_{2} \mathrm{O}$ dose, cabbage culture matured faster, and better production and quality were obtained. Tiwari et al. (2014) mention that by applying potassium fertilizers, cabbage production increased by $29 \%$. Similarly, research by Din et al. (2007) highlights the significantly favourable effect of potassium fertilization on production and quality in white cabbage crops. After 140 days of cold storage of the 'De Buzau' cultivar, the effect of applying calcium carbonate amendments and potassium fertilization to acidic soils and with low availability of easily accessible potassium was achieved by maintaining the quality of stored cabbage, depending on soil characteristics and the applied inputs (Table 7).

The losses generated by evapotranspiration were smaller (considering the absolute values of the losses, as average of locations) for cabbage produced on limestone amended surfaces. In this case, evapotranspiration losses were significantly lower, by $3.7 \%$; potassium salt fertilization of experimental plots also led to the losses reduction caused by evapotranspiration; there was a difference of $1.5 \%$ weight loss between the variants. This difference was, however, insignificant from a statistical point of view. Applying dolomitic limestone on the fields for cabbage culture, prior to seedlings transplantation, under the conditions of an acidic $\mathrm{pH}$ soil (4.8-5.4), led to increased production and reduced weight loss due to evapotranspiration during storage (Maynard, 1965; Cutcliffe, 1984),

The losses generated by decay and conditioning were significantly lower for cabbage coming both from calcium carbonate amended surfaces and potassium salt fertilized ones $\left(240 \mathrm{kgha}^{-1}\right.$ active substance $\left.\mathrm{K}_{2} \mathrm{O}\right)$, by $4.4 \%$, respectively by $2.6 \%$. The results are in line with those presented by Devocikin (1967) Ziegler and Böttcher (1966), who, by cultivating cabbage on different fertilization variants, identified in the variant with the highest potassium content (3.66\%), the cabbage heads with the highest specific weight, with the lowest loss due to decay at the end of the storage cycle.

After storage period, total losses registered were significantly lower by $8.1 \%$ for cabbage harvested on limestone amended plots, and by $4.1 \%$ for the variants fertilized with potassium, comparative with control variant. The results reported by Skripnikov (1971) are similar to those presented, showing that "the fertilization of the cabbage culture with potassium doses improved storage capacity, while increased nitrogen doses and low temperature during seedling growth, diminished the storage capacity and increased losses". 


\section{Conclusions}

The effect of calcium carbonate treatment and potassium salt fertilization on acid podzolic soils poorly supplied with potassium, cultivated with white autumn cabbage, determined improvement of some biochemical and physiological quality indicators( soluble dry substance, soluble carbohydrates, chlorophyll pigments, permeability index), achieving and maintaining a $(\mathrm{Ca} / \mathrm{Mg})$ ratio very close to the optimal value, a significant increase in marketable production and significant reduction of losses in the long-term storage process of cabbage.

\section{Acknowledgements}

This work was supported by the Internal Project number 3/2015, financed by ICDIMPH - HORTING”.

\section{References}

Adams P (1991). Effects of increasing the salinity of the nutrient solution with major nutrients or sodium chloride on the yield, quality and composition of tomatoes grown in rockwool. Journal of Horticultural Science 66:201-207.

Atanasova E, Mitova I, Dimitrov I, Stancheva I (2007). Effects of different fertilizer sources on the quality of head cabbage. Journal of Applied Horticulture 9(1):74-76.

Beecher C (1994). Cancer preventive properties of varieties of Brassica oleracea: a review. The American Journal of Clinical Nutrition 59(11):66S-70S.

Bhardwaj ML, Raj H, Koul BL (2000). Yield response and economics of organics sources and inorganic source in tomato (Lycopersicon esculetum), okra (Hibiscus esculents), cabbage (Brassica oleraceae). Indian Journal of Agricultural Science 70(10):653-656.

Bidari BI, Hebsur NS (2011). Potassium in relation to yield and quality of selected vegetable crops. Karnataka Journal of Agricultural Sciences 24(1):55-59.

Burzo I, Voican A, Bogoescu M (1990). Cercetări privind transportul ionilor prin membranele plasmatice la unele specii de legume, fructe şi flori [Researches on the transport of ions through plasma membranes to some species of vegetables, fruits and flowers]. Lucrari Stiintifice USAB Seria B 36:7-14.

Cutcliffe JA (1984). Effects of added limestone and potassium on yield and storage losses of cabbage. Canadian Journal of Plant Science 64(4):395-399.

Devocikin L (1967). Himiceskii sostev iliokjest kapustî [Chemical composition of cabbage]. Preizvodnecernoz zonî 5:12.

Din M, Qasim M, Alam M (2007). Effect of different levels of N, P and $\mathrm{K}$ on the growth and yield of cabbage. Journal of Agricultural Research 45(2):171-177.

FAO (2000). Statistical database food and Agricultural Organization of the United Nations, Rome, Italy. Retrieved 2017 February 12 from www.fao.org/statistics/databases/en/.

FAO (2014). Statistical database food and Agricultural Organization of the United Nations, Rome, Italy. Retrieved 2017 February 12 from www.fao.org/statistics/databases/en/.
Fowke JH, Chung FL, Jin F, Qi D, Cai Q, Conaway C, ChengJR, Shu XO, Gao YT, Zheng W (2003). Urinary isothiocyanate levels, Brassica and human breast cancer. Cancer Research 63:3980 - 3986.

Geissler T (1953). Über die wirkung chlorid and sulfathaltiger Dungemittel auf den Ertrag einiger Gemüsearten [On the effect of chloride and sulphate fertilizer on the yield of some kinds of vegetables]. Archiv für Gartenbau 1:233-243.

Ghuge TD, Gore AK, Jadhav SB (2007). Effect of organic and inorganic nutrient sources on growth, yield and quality of cabbage (Brassica oleracea var. capitata). Journal of Soils and Crops 17(1):89-92.

Gould S, Tkesslee DK, King CG (2006). Vitamin-C content of vegetables, v. cabbage. Journal of Food Science 1(5):427-434.

Guo XS, Zhu HB, Wang WJ, Ye SY, Wu J, Wu LS (2004). Effect of different rates of nitrogen and potash on yield and quality of cabbage. Plant Nutrition Fertilization Science 10(2):161-166.

Iakovskaia MM (1967). Vliianie udrobanii na himiceskii sesta kapustî i morovii [The effect of ripening on the chemical composition of cabbage and carrots]. Him.s.h. 5(5):92-95.

Lester GE, Jifon JL, Rogers G (2005). Supplemental foliar potassium applications during muskmelon fruit development can improve fruit quality, ascorbic acid, and beta-carotene contents. Journal of the American Society for Horticultural Science 130(4):649-653.

Marschner H (2011). Marschner's mineral nutrition of higher plants, 3rdEd. Academic Press.

Maynard DN, Gersten B, Vernell HP (1965). The distribution of calcium as related to internal tipburn, variety, and calcium nutrition in cabbage. In: Proceedings American Society Horticultural Sciences 86:392-396.

Nilsson J, Olsson K, Engqvist G, Ekvall J, Olsson M, Nyman M, Accession B (2006). Variation in the content of glucosinolates, hydroxycinnamic acids, carotenoids, total antioxidant capacity and low-molecular-weight carbohydrates in Brassica vegetables. Journal of the Science of Food and Agriculture 86:528-538.

NIS (2015). TEMPO database. Retrieved 2017 February 12 from www.statistici.insse.ro/shop/index.jsp?Page=tempo2\&lang=ro\&c ontext $=45$.

Ojetayo AE, Olaniyi JO, Akanbi WB, Olabiyi TI (2011). Effect of fertilizer types on nutritional quality of two cabbage varieties before and after storage. Journal of Applied Biosciences 48:3322-3330.

Rao MH, Subramanian TR (1991). Effect of potassium application on the yield content of potassium, calcium and magnesium cabbage, okra, tomato and bee-root. Journal of Agricultural Research $7(3): 190-197$.

Shika A, Doug W (2001). Cabbage - post-harvest, handling and storage. Department of Plant Science, Univ Saskatchewan. Retrieved 2017 February 12 from http://www.agr.gc.ca/resources/prod/doc/pfraarap/csidc-crdi/pdf/cabbage-chou_eng.pdf.

Sima R, Măniuțiu D, Apahidean A, Apahidean M, Lazăr V, Sima N (2014). The influence of technological inputs on yield and quality traits of greenhouse cabbage. Bulletin UASVM Horticulture ClujNapoca 71(2):308-312.

Skripnikov JG (1971). The storage of cabbage and carrots for seed production. Acta Horticulturae 20:19-24. 
Tiwari DD, Pandey SB, Katiyar NK (2014). Effect of graded doses of potassium on yield, profitability and nutrient content of vegetable crops in the Central Plain Zone of Uttar Pradesh, India. Retrieved 2017 February 12 form https://www.ipipotash.org/en/eifc /2014/38/3/english.

Vanparys L, Seynnaeve M (1998). White cabbage. Effect of fertilizers and cultivar choice in stored cabbage. Proeftuinnieuws 8(13):37-38.

Wang XP, Shan XQ,ZhangSZ, Wen B (2004). A model for evaluation of the phytoavailability of trace elements to vegetables under the field conditions. Chemosphere 55:811-822.

Welch NC, Tyler KB, Ririe (1985). Cabbage yield and nutrient uptake. California Agriculture 39(7):30-32.
Wijevardena JDH, Amarasiri SL (1993). Response of vegetable crops in a cropping sequence to $\mathrm{K}$ and $\mathrm{Mg}$ fertilizers in the upcountry intermediate zone. Tropical Agriculturist 149:13-22.

Zhou Y, Huang F, Wang ZX, Zhu JH (2001). Effect of potash application on early ripening and yield of cabbage. Better Crops International 15(2):14-16.

Ziegler C, Böttcher H (1966). Ein Beitrag zu Fragen der Stickstoff- und Kaliwirkung auf Flächenertrag und Haltbarkeit von Weißkohl [Contributions concerning the influence of $\mathrm{N}$ and $\mathrm{K}$ on the yield and storage capacity of white cabbage]. Archiv für Gartenbau 14(8):513-535. 